\title{
The Esthetic Crown Lengthening by Er;Cr:YSGG laser: A Case Series
}

\author{
Reza Fekrazad', Mohammad Moharrami ${ }^{2}$, Nasim Chiniforush ${ }^{3 *}$ \\ ${ }^{1}$ Laser Research Center in Medical Sciences (LRCMS), Department of Periodontics, Faculty of Dentistry, AJA University of \\ Medical Sciences, Tehran, Iran \\ ${ }^{2}$ Tehran University of Medical Sciences, Tehran, Iran \\ ${ }^{3}$ Laser Research Center of Dentistry, Dentistry Research Institute, Tehran University of Medical Sciences, Tehran, Iran
}

\author{
*Correspondence to \\ Nasim Chiniforush, DDS, PhD; \\ Laser Research Center of Dentistry, \\ Dentistry Research Institute, Tehran \\ University of Medical Sciences, \\ Tehran, Iran. \\ Tel/ Fax: +982188994824 \\ Email: \\ n-chiniforush@farabi.tums.ac.ir
}

Published online 17 September 2018

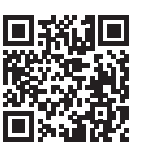

\section{Introduction}

The modern dentistry is based on safety and minimum invasive procedures. In order to achieve this goal new instruments and materials have been developed. ${ }^{1}$ One of these newly developed instruments is laser which comes in handy in many fields of dentistry like dental bleaching, crown lengthening (CL), restoratives, endodontic and implant surgeries. ${ }^{2-4}$

Several lasers and different wavelengths have been developed for cavity preparations instead of conventional technique performing by rotary instruments which do the hard tissue cutting based on biological and mechanical principles. Some advantages are named for lasers over rotary drills such as; safety, pain reduction, comfortably, reduction of noise and vibrations. ${ }^{4-7}$ In order to gain these benefits and optimum efficacies, some clinical studies have suggested yttrium-aluminum-grant (Er:YAG) and erbium, chromium: yttrium-scandium-gallium-garnet (Er,Cr:YSGG) lasers for cavity preparation. ${ }^{8}$ Er,Cr:YSGG alongside with Er:YAG has the safest and the best characteristic for precise dental procedures. ${ }^{9}$

Recent studies and experiments mostly focused on usage of Er; Cr:YSGG in cavity preparation due to the emission of $2.78 \mu \mathrm{m}$ wavelength. It is perfectly absorbed by water and hydroxyapatite which form the most percentage of bone and dentin; the subsequent reactions bring about ablation of bone tissues and tooth. ${ }^{8}$ There are several reasons for choosing Er;Cr:YSGG laser in restorative dentistry; among those the important factor which attract clinicians to choose Er;Cr:YSGG seems to be its subtle selectivity in removing caries. Caries contain larger amount of water in comparison with healthy dentin, thus, the irradiations are better absorbed by caries and make the selective removal possible ${ }^{8}$; in most cases no need for anesthesia, no adverse reaction, patients satisfaction and good prognosis are other advantages mentioned for Er;Cr:YSGG. ${ }^{10}$

Besides the proven benefits of Er;Cr:YSGG laser in cavity preparation and remarkable results in hard tissues management, it is also an appropriate instrument for soft tissue surgeries like the exposure of unerupted teeth, lingual and maxillary frenectomies, gingivectomy, excision of pyogenic granuloma and pulpotomy. ${ }^{11}$ In some case series, acceptable flapless CL has been demonstrated 
as well. ${ }^{12}$ It is shown that using this laser can do effective minimally invasive operations and help soft tissue management during restorative procedures. ${ }^{13}$

There are several indications for CL; aesthetic enhancement by correcting and modifying surplus gingiva display and bone referred as "gummy smile"; revealing adequate tooth structure for restorative treatments of fractured teeth and removing subgingival carries, ${ }^{14,15}$ however, there are some contraindications for its usage as well like teeth with high furcation and endangerment of stability in cases of excessive osseous resections due to unacceptable crow-root ratio. ${ }^{16}$ When a clinician intends to do soft tissue CL, it should be keep in mind not to violate biological width; in cases which there is less than $3 \mathrm{~mm}$ of attached gingiva apically positioned flap must be considered as an alternative; in these cases gingivectomy results in complete removal of attached gingiva. ${ }^{14}$

CL can be accomplished by scalpel, electrosurgery, bur or lasers, in cases of external beveling lasers can be a suitable choice. Also, hard tissue can be removed in minimally invasive manner. In that case, the surgery causes little bleeding thus make it possible to handle the final restoration in a dry field which leads better results. ${ }^{17}$ Due to mentioned features of lasers for soft and hard tissue managment, this study presents series of cases of CL and restorations accomplished by Er;Cr:YSGG.

\section{Methods}

Six female and 1 male patients for CL and composite restorations of anterior teeth aged between 20 to 60, were selected for this study. The patients referred to private practice for aesthetic reasons. They were unhappy with their smile and demanded consultant, thus, laser treatment was suggested. Patients had no specific local or systemic disease which could affect teeth or gingiva. The patients had no previous treatment on current teeth. Prior to the surgery patient photos were analyzed and for those who needed CL, the approximate location of new gingiva was defined with respect to gingival margin and bone to maintain acceptable biological width; the finish point of surgery and the new location of gingival margin did not trespass cement enamel junction (CEJ). Patients' oral hygiene and periodontal health were evaluated as well.

All patients treated with Er;Cr:YSGG Laser producing a wavelength of $2780 \mathrm{~nm}$ (Biolase, Irvine, California, USA)); Tip T4, $400 \mu \mathrm{m}$ diameter for soft tissue management and Tip G6, $6 \mathrm{~mm}$ long, $600 \mu \mathrm{m}$ diameter for hard tissue management. Under local anesthesia (Xylocaine 2\% with Adrenaline (Epinephrine) 1:200,000). The area of operation was dried and Gingivectomy was performed carefully following the curvature of the marginal crest. The margin then contoured using the same tip. No periodontal dressing was used to cover the area of operation. Patients were prescribed to not to brush surgical area and use warm normal saline for cleaning.

\section{Cases}

Patient 1: 32-year-old female patient with carries existing on buccal surfaces of teeth 12 and 13. The teeth were sensitive during brushing and the patient was unhappy with her smile. The soft tissue was removed by Er;Cr:YSGG laser with output power of $1.5 \mathrm{~W}, 20 \mathrm{~Hz}, 20 \%$ water/ $30 \%$ air, pulse duration of $140 \mu$ s. Then, the caries were removed with Er;Cr:YSGG with output power of 3 $\mathrm{W}, 20 \mathrm{~Hz}, 50 \%$ water, $60 \%$ air, pulse duration of $140 \mu \mathrm{s}$ and conditioning was also done with laser with output power of $1 \mathrm{~W}, 20 \mathrm{~Hz}, 20 \%$ water/ $30 \%$ air. As it is seen no bleeding occurred and patient felt comfortable and reported no pain. The final restorative was accomplished using $3 \mathrm{M}$ ESPE restorative composite resin and Scotchbond ${ }^{\mathrm{TM}}$ Universal Adhesive bonding immediately after the laser therapy (Figure 1).

Patient 2: 21 years old female, one-sided gummy smile, gingiva of teeth 21, 22, 23 descendent. The patient was unhappy with her smile, no pocket was detected but the bleeding was seen on probing due to hemangioma lesion which extended from buccal mucosa to depth of vestibule, the conditions of teeth were acceptable, therefore no restorative phase was needed. Gingivectomy was accomplished by Diode laser (Twilight, Biolase Technologies, USA) with wavelength of $810 \mathrm{~nm}$ with output power of $4 \mathrm{~W}$, chopped mode with pulse duration of $20 \mathrm{~ms}$ and interval of $20 \mathrm{~ms}$. The fiber of $400 \mu \mathrm{m}$ was used in this patient. The patient was satisfied with the final result. No serious bleeding occurred and
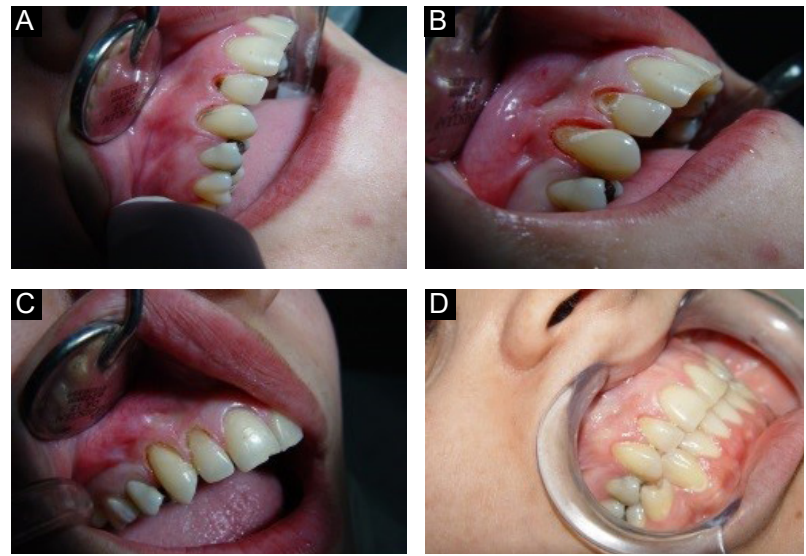

Figure 1. (A) Preoperative View. (B) After Carries Removal. (C) Final Restoration. (D) Five-Year Follow up.
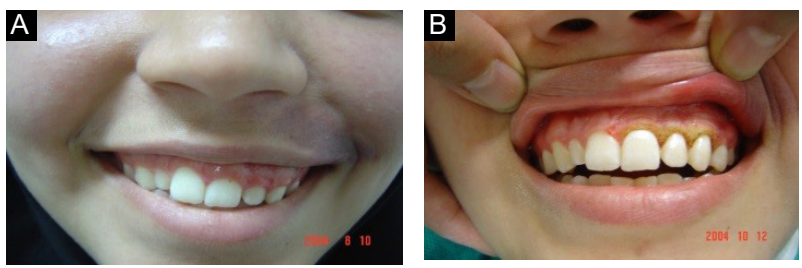

Figure 2. (A) Preoperative View. (B) Postoperative View. 
the patient felt little pain. She was prescribed to use warm normal saline as mouthwash (Figure 2).

Patient 3: 24 years old female, two-sided gummy smile with high attached frenum. The patient was unhappy with her smile and felt her teeth are short and gingiva is too long. The patient was allergic to penicillin. There was no pocket or bleeding on probing. Clinical crown seemed shorter than the anatomical crown. As it is seen tooth 21, $22,23,24,11,12,13$ and 14 needed buccal CL. Firstly, the right quadrant undertook the procedure. The gingiva was removed by Er;Cr:YSGG laser with output power of 1.5 W, $20 \mathrm{~Hz}, 20 \%$ water/ $30 \%$ air, pulse duration of $140 \mu \mathrm{s}$. Then, the bone removal was done by output power of 3 W, $20 \mathrm{~Hz}, 50 \%$ water/ 60\% air. After a week labial frenum was dissected with power of $2 \mathrm{~W}, 20 \mathrm{~Hz}, 30 \%$ water/ $45 \%$ air and CL took place on upper left quadrant with the same parameters of right quadrant. Three weeks follow up indicated acceptable results; the patient was satisfied as well (Figure 3).

The CL for patient 4 was done like patient 3 (Figure 4). Patient 5 was a 63 year-old-man with sever attrition who underwent the same treatment plan of patient 1 (Figure 5). Patient 6 which had complaint about color of her teeth was treated by Er;Cr:YSGG laser for both soft and hard tissue and after final conditioning of teeth by laser, composite facing was done (Figure 6). In last case, frenectomy and CL was done by erbium laser and the crown was replaced by new one. No side effect was reported and patients' smile and aesthetics were improved
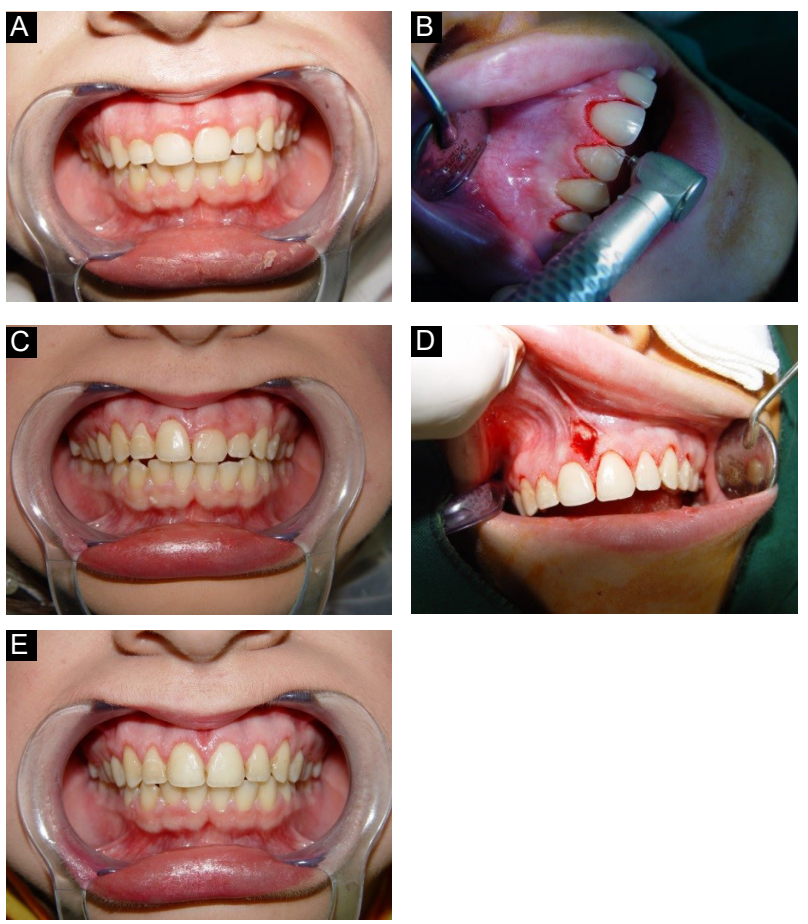

Figure 3. (A) Preoperative View. (B) Crown Lengthening (CL) Using Er; Cr:YSGG. (C) After 1 Week. (D) Frenectomy Using Er;Cr:YSGG. (E) Postoperative View After 3 Weeks Follow up significantly (Figure 7).

\section{Discussion}

There are 2 main indications for CL; functional and aesthetic, each category focus on specific treatments. Aesthetic usually consider treatment of short clinical crowns, improving gingival symmetry, correcting uneven gingival margins and modifying hyperplastic tissue overgrowth. ${ }^{18}$ The aesthetic procedure could be performed using traditional scalpel surgical procedures or lasers. Precision, sterilization, bloodless surgical and post-surgical course, no need for sutures, less pain and swelling and better prognosis are advantages of lasers over traditional surgeries. ${ }^{19}$

It is also shown that both Er;Cr:YSGG and Er:YAG laser are efficient and effective for class $\mathrm{V}$ cavity preparation and making similar morphological features on the surfaces of operation. ${ }^{20}$ Er;Cr:YSGG laser is also capable of making tooth enamel more resistant to caries by elevating
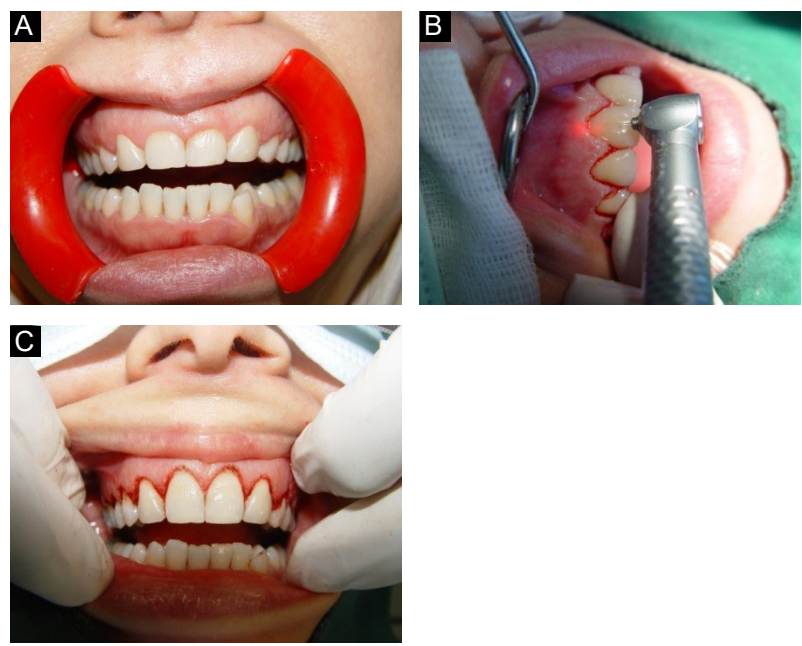

Figure 4. (A) Preoperative View. (B) Crown Lengthening (CL) of teeth $11,12,13,14 \& 21,22,23,24$. (C) Postoperative View.
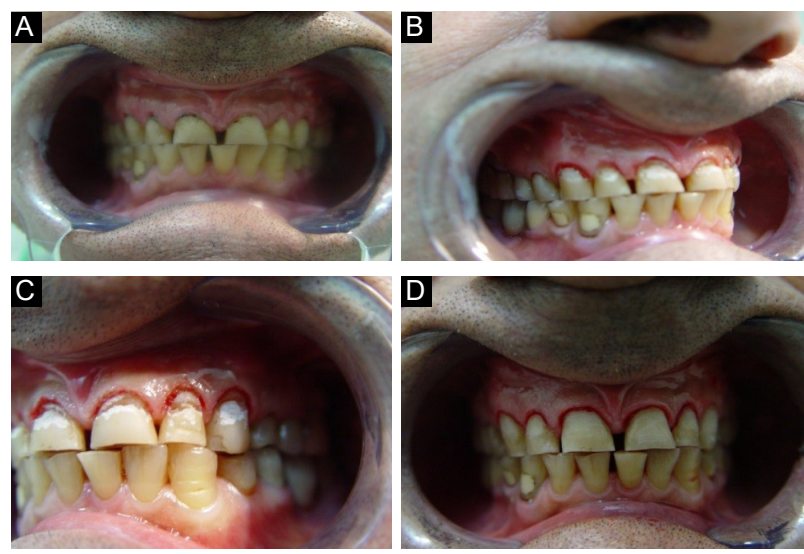

Figure 5. (A) Preoperative View. (B) Crown Lengthening (CL) and Caries Removal of Teeth 13, 12, 11. (C) Crown Lengthening (CL) and Caries Removal of Teeth 21, 22, 23. (D) Final Restoration. 

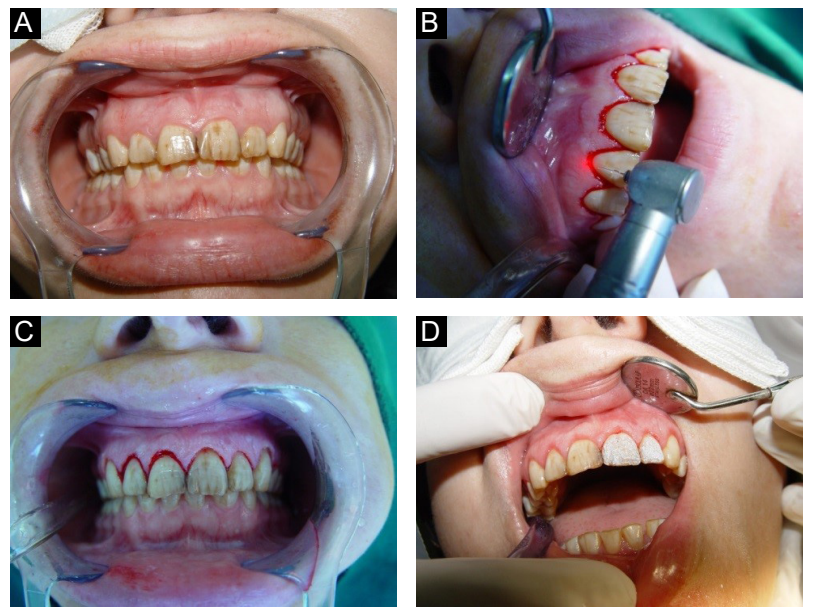

Figure 6. (A) Preoperative View. (B) Crown Lengthening (CL) of Teeth 13, 12, 11, 21, 22, 23. (C) Immediate Postoperative. (D) After 1 Month Follow up.

its resistance against acid. ${ }^{21}$ However, in order to get best results and benefit from all potentials of Er;Cr:YSGG laser, some consideration must be followed like using water spray at ablation site performing as an initiator for ablation of dental hard tissue and increases the depth of prepared cavity. ${ }^{22}$

Er;Cr:YSGG laser is not only beneficial for adults but also showed great results for soft tissue management in children aged 6 to 14 years old were for problems like CL, exposure of an unerupted molar, lingual and maxillary frenectomies, gingivectomy, excision of a pyogenic granuloma. ${ }^{11,23}$

Up to this date, some case series studies' results showed the effectiveness and non-invasive features of lasers in the management of soft tissue, ${ }^{13}$ cavity preparation and caries removal. ${ }^{10}$ Little need of injection for hard tissue management and no need of anesthesia in soft tissue removal are the advantages of erbium laser in esthetic procedures.

In this study, Er;Cr:YSGG with water spray was served for class $\mathrm{V}$ cavity preparation in 2 patients, the results were satisfying as no post-operative pain or bleeding occurred and final restoration could be done immediately after preparation, no adverse effect was seen during 3 months to 7-year follow up. The aesthetic of final restoration was acceptable as well. However, the longer time spent for cavity preparation compared with conventional technique is improved by new productions.

Closed flap CL performed with Er;Cr:YSGG as well; the external bevel gingivectomy for soft tissue was chosen as appropriate technique based on sufficient attached gingiva in all cases. The final width of attached gingival was not less than $3 \mathrm{~mm}$. The laser bandage was performed as an additional step to accelerate healing and reducing pain and bleeding. No suture was needed for any cases and there was no report of swelling, trauma or discomfort from any of patients. With all these saying, it must be
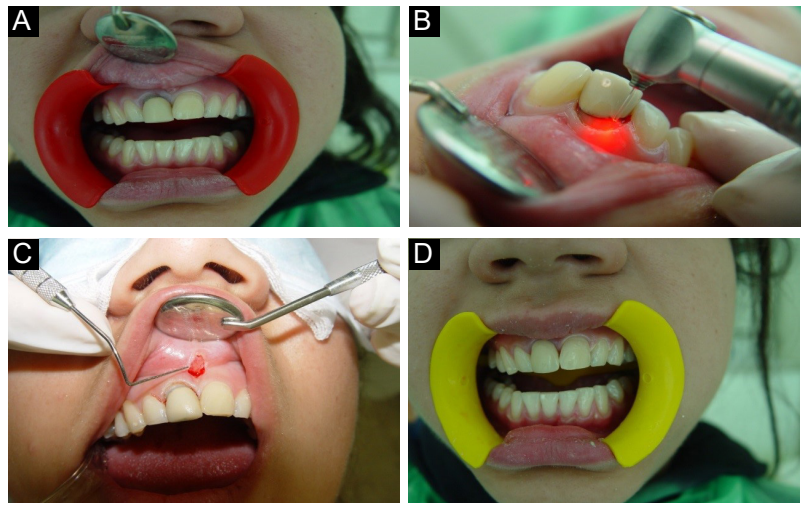

Figure 7. (A) Preoperative View. (B) Crown Lengthening (CL) of Tooth 11. (C) Frenectomy Using Er;Cr:YSGG. (D) Postoperative View.

noticed this technique cannot be done for all CL cases but it certainly helps practitioners to minor surgical cosmetic cases. $^{24}$

The numbers of references associated with flapless CL using lasers as minimally invasive procedure have increased during recent years, and the majority of these studies are case reports or case series. These studies are valuable, furthermore, initial attempts towered demonstrating clinical advantages and capability of lasers in this field, thus prospective randomized controlled studies are needed to categorize this approach as standard procedure for CL. ${ }^{12}$

Having sufficient knowledge and experience regarding laser-tissue interaction (soft and hard tissues) is necessary to choose the appropriate parameters, which results in good prognosis. So, the application of a new technology should be accompanied by following basic treatment rules to achieve the best results.

\section{Conclusion}

Using Er;Cr:YSGG laser can be considered as valuable device for both soft and hard tissue surgery due to its advantages like producing less pain, reasonable bleeding, less post-operative complications and accelerated healing time compared to conventional method.

\section{Conflict of Interests}

Authors declare that there is no conflict of interest.

\section{Ethical Considerations}

The informed consent was signed by all patients.

\section{References}

1. Peters MC, McLean ME. Minimally invasive operative care. II. Contemporary techniques and materials: an overview. J Adhes Dent. 2001;3(1):17-31.

2. Lizarelli RFZ, Costa MM, Carvalho-Filho E, Nunes FD, Bagnato VS. Selective ablation of dental enamel and dentin using femtosecond laser pulses. Laser Phys Lett. 2008;5(1):63-69. doi:10.1002/lapl.200710082

3. Malta DAMP, Costa M, Pelino JEP, de Andrade MF, Lizarelli 
RFZ. Bond strength of an adhesive system irradiated with Nd:YAG laser in dentin treated with Er:YAG laser. Laser Phys Lett. 2008;5(2):144-150. doi:10.1002/lapl.200710089

4. Stubinger S. Advances in bone surgery: the Er:YAG laser in oral surgery and implant dentistry. Clin Cosmet Investig Dent. 2010;2:47-62.

5. Keller U, Hibst R, Geurtsen W, et al. Erbium:YAG laser application in caries therapy. Evaluation of patient perception and acceptance. J Dent. 1998;26(8):649-656.

6. Parhami P, Pourhashemi SJ, Ghandehari M, Mighani G, Chiniforush N. Comparative Study of the Shear Bond Strength of Flowable Composite in Permanent Teeth Treated with Conventional Bur and Contact or NonContact Er:YAG Laser. J Lasers Med Sci. 2014;5(3):140-145.

7. Fekrazad R, Chiniforush N. One visit providing desirable smile by laser application. J Lasers Med Sci. 2014;5(1):4750 .

8. Santos CR, Tonetto MR, Presoto CD, et al. Application of Er:YAG and Er, Cr:YSGG Lasers in Cavity Preparation for Dental Tissues: A Literature Review. World J Dent. 2012;3(4):340-343. doi:10.5005/jp-journals-10015-1186

9. Diaci J, Gaspirc B. Comparison of Er: YAG and Er, Cr: YSGG lasers used in dentistry. Review. J laser health Acad. 2012;1(1):1-13.

10. Matsumoto K, Hossain M, Hossain MM, Kawano H, Kimura Y. Clinical assessment of Er,Cr:YSGG laser application for cavity preparation. J Clin Laser Med Surg. 2002;20(1):17-21. doi:10.1089/104454702753474968

11. Boj JR, Poirier C, Hernandez M, Espassa E, Espanya A. Case series: laser treatments for soft tissue problems in children. Eur Arch Paediatr Dent. 2011;12(2):113-117.

12. McGuire MK, Scheyer ET. Laser-assisted flapless crown lengthening: a case series. Int J Periodontics Restorative Dent. 2011;31(4):357-364.

13. Jetter C. Soft-tissue management using an Er,Cr:YSGG laser during restorative procedures. Compend Contin Educ Dent. 2008;29(1):46-49.

14. Hempton TJ, Dominici JT. Contemporary crownlengthening therapy: a review. J Am Dent Assoc. 2010;141(6):647-655.
15. Levine RA, McGuire M. The diagnosis and treatment of the gummy smile. Compend Contin Educ Dent. 1997;18(8):757762, 764; quiz 766.

16. Dibart S, Capri D, Kachouh I, Van Dyke T, Nunn ME. Crown lengthening in mandibular molars: a 5-year retrospective radiographic analysis. J Periodontol. 2003;74(6):815-821. doi:10.1902/jop.2003.74.6.815

17. Farista S, Kalakonda B, Koppolu P, Baroudi K, Elkhatat E, Dhaifullah E. Comparing Laser and Scalpel for Soft Tissue Crown Lengthening: A Clinical Study. Glob J Health Sci. 2016;8(10):55795. doi:10.5539/gjhs.v8n10p73

18. Gokulanathan S, Mathews D, Daniel R, Ahathya R. Crown lengthening using diode laser: A case series. J Indian Acad Dent Spec Res. 2014;1(2):77-79. doi:10.4103/22293019.148272

19. Pick RM, Colvard MD. Current status of lasers in soft tissue dental surgery. J Periodontol. 1993;64(7):589-602. doi:10.1902/jop.1993.64.7.589

20. Harashima T, Kinoshita J, Kimura Y, et al. Morphological comparative study on ablation of dental hard tissues at cavity preparation by Er:YAG and Er,Cr:YSGG lasers. Photomed Laser Surg. 2005;23(1):52-55. doi:10.1089/ pho.2005.23.52

21. Geraldo-Martins VR, Lepri CP, Palma-Dibb RG. Influence of Er,Cr:YSGG laser irradiation on enamel caries prevention. Lasers Med Sci. 2013;28(1):33-39. doi:10.1007/ s10103-012-1056-9

22. Hossain M, Nakamura $Y$, Yamada $Y$, Kimura $Y$, Matsumoto N, Matsumoto K. Effects of Er,Cr:YSGG laser irradiation in human enamel and dentin: ablation and morphological studies. J Clin Laser Med Surg. 1999;17(4):155-159. doi:10.1089/clm.1999.17.155

23. Fekrazad R, Nokhbatolfoghahaei H, Khoei F, Kalhori KA. Pyogenic Granuloma: Surgical Treatment with Er:YAG Laser. J Lasers Med Sci. 2014;5(4):199-205.

24. Chen CK, Wu YT, Chang NJ, et al. Er:YAG Laser for Surgical Crown Lengthening: A 6-Month Clinical Study. Int J Periodontics Restorative Dent. 2017;37(2):e149-e153. doi:10.11607/prd.2551 